\title{
Folate deficiency presenting as pyrexia: a case report
} Aran Singanayagam*1, Nisal Gange ${ }^{1}$, Anika Singanayagam ${ }^{2}$ and Hywel Jones ${ }^{1}$

\author{
Address: ${ }^{1}$ Department of Acute General Medicine, John Radcliffe Hospital, Headley way, Headington, Oxford, OX3 9DU, UK and ${ }^{2}$ University of \\ Oxford, Department of Medical Sciences, John Radcliffe Hospital, Headley way, Headington, Oxford, OX3 9DU, UK \\ Email: Aran Singanayagam* - aransinga@gmail.com; Nisal Gange - nhgange@hotmail.com; Anika Singanayagam - anika.singa@gmail.com; \\ Hywel Jones - hyweljones@orh.nhs.uk \\ * Corresponding author
}

Published: 26 October 2008

Cases Journal 2008, I:275 doi:10.1 186/1757-1626-1-275

This article is available from: http://www.casesjournal.com/content/I/I/275

(c) 2008 Singanayagam et al; licensee BioMed Central Ltd.

This is an Open Access article distributed under the terms of the Creative Commons Attribution License (http://creativecommons.org/licenses/by/2.0), which permits unrestricted use, distribution, and reproduction in any medium, provided the original work is properly cited.

Received: 8 August 2008

Accepted: 26 October 2008

\begin{abstract}
Folate deficiency is an uncommon cause of pyrexia. We describe the case of a 29-year-old male who presented with a pyrexial illness subsequently attributed to megaloblastic anaemia secondary to severe folate deficiency, after exclusion of other infective or inflammatory causes. A temperature chart documenting the course of the patient's pyrexia is presented and potential pathophysiological mechanisms are proposed. Folate deficiency is a reversible cause of pyrexia that should be considered in any patient who presents with a pyrexial illness of unknown cause.
\end{abstract}

\section{Case presentation}

A 29-year-old caucasian male presented to our medical admissions unit complaining of a 6 week history of dyspnoea on exertion, recurrent fevers and sweats. He had a 7 year history of alcohol excess, drinking 3-4 litres of cider per day. He was a smoker of 10 cigarettes per day, but was otherwise fit and well with no significant past medical or family history. The patient reported no other symptoms and did not take any regular medication.

Examination revealed a pulse rate of 124 beats/minute and a blood pressure of $120 \mathrm{mmHg} / 48 \mathrm{mmHg}$. He was noted to be febrile with a temperature of $38.8^{\circ} \mathrm{C}$. Oxygen saturations were $100 \%$ on room air with no signs of respiratory distress. He had visibly pale conjunctiva and a lemon yellow tint to the skin (but no evidence of icteric sclerae). There were no signs of chronic liver disease and no peripheral stigmata of bacterial endocarditis. Cardiovascular examination revealed a collapsing pulse and a soft systolic murmur audible at the left sternal edge. Auscultation of the chest revealed vesicular breath sounds with no added sounds. On abdominal examination there was palpable splenomegaly but not other organomegaly or ascites. Neurological examination was normal with was no evidence of neck stiffness or skin rashes.

Admission blood tests revealed a severe pancytopenia with a raised mean cell volume (see table 1). Also notable was a mild hyperbilirubinaemia but otherwise normal liver function with no evidence of impaired hepatic synthetic function (normal serum albumin and normal prothrombin time).

Subsequently, serum folate levels were found to be low at $1.2 \mathrm{ug} / \mathrm{L}$ (normal range 4-24 ug/L) and vitamin $\mathrm{B}_{12}$ levels were low-normal at $202 \mathrm{ng} / \mathrm{L}$ (normal range 180-900 ng/ L). Iron studies were normal. Initial blood film and subsequent bone marrow examination confirmed a severe megaloblastic picture, consistent with folate deficiency.

Urine dip test and subsequent urine cultures were negative. Three sets of blood cultures were taken from different sites (before commencement of antibiotics) but were all negative after 5 days culture. Chest radiograph was nor- 
Table I: Baseline investigations on admission

\begin{tabular}{|c|c|c|}
\hline & & Normal range \\
\hline Haemoglobin (g/dL) & 2.8 & $13.0-17.0$ \\
\hline Mean cell volume ( $\mathrm{fL}$ ) & 112 & $83-105$ \\
\hline Platelet count $(\times 109 / \mathrm{L})$ & 26 & $150-400$ \\
\hline White cell count $\left(\times 10^{9} / \mathrm{L}\right)$ & 2.6 & $4.0-11.0$ \\
\hline Neutrophils $\left(\times 10^{9} / \mathrm{L}\right)$ & 1.22 & $2.0-7.0$ \\
\hline Lymphocyte $(\times 109 / \mathrm{L})$ & 1.24 & $1.0-4.0$ \\
\hline Monocytes $\left(\times 10^{9} / \mathrm{L}\right)$ & 0.10 & $0.2-1.0$ \\
\hline Reticulocyte count & $8.85 \%$ & $0.5-1.5 \%$ \\
\hline Prothrombin time (secs) & 13.9 & $12.0-14.0$ \\
\hline Activated partial thromboplastin time (secs) & 35 & $30.0-45.0$ \\
\hline Sodium (mmol/L) & 130 & $135-145$ \\
\hline Potassium (mmol/L) & 3.2 & $3.5-5.0$ \\
\hline Urea (mmol/L) & 6.4 & $2.5-6.7$ \\
\hline Creatinine (umol/L) & 89 & $70-150$ \\
\hline C-Reactive Protein (mg/L) & 28 & $0-8$ \\
\hline Total bilirubin (umol/L) & 28 & $3-17$ \\
\hline Alanine transferase (iU/L) & 15 & $10-45$ \\
\hline Alkaline Phosphatase(iU/L) & 110 & $96-280$ \\
\hline Gamma GT (iU/L) & 24 & $15-40$ \\
\hline Albumin $(g / L)$ & 38 & $35-50$ \\
\hline Thyroid stimulating hormone (mU/L) & 3.56 & $0.35-5.5$ \\
\hline
\end{tabular}

mal with no evidence of focal consolidation. Abdominal ultrasound confirmed splenomegaly but liver size and architecture was normal. A full auto-antibody screen was sent but found to be negative (see table 2).

\section{Clinical progression}

Initially, the patient was started on intravenous broad spectrum antibiotics as he was presumed to be pyrexial secondary to underlying sepsis of unknown origin. However, despite antibiotics, he did not improve rapidly and continued to remain intermittently pyrexial. Therefore, in the absence of any positive microbiological tests, antibiotics were stopped with continuation of $\mathrm{B}_{12}$ and folate supplementation alone. Pyrexia settled on day 4 without any further antimicrobial or anti-inflammatory therapy (see figure 1).

Symptomatically, the patient improved gradually after commencement of $\mathrm{B}_{12}$ and folate supplementation on day

Table 2: Autoimmune screen

\begin{tabular}{llc}
\hline & & Normal range \\
\hline Anti-nuclear antibodies & Negative & \\
Anti smooth muscle antibodies & Negative & \\
Anti mitochondrial antibodies & Negative & \\
Anti Gastric parietal cell antibodies & Negative & \\
Anti LKM antibodies & Negative & \\
Complement C3 & 77.5 & $65-190 \mathrm{mg} / \mathrm{dL}$ \\
Complement C4 & 20.8 & $14-40 \mathrm{mg} / \mathrm{dL}$ \\
Rheumatoid factor & $<10.0 \mathrm{IU} / \mathrm{mL}$ & \\
& &
\end{tabular}

Table 3: Progression of laboratory parameters

\begin{tabular}{lccccc}
\hline & Day I & Day 2 & Day 3 & Day 5 & Day 7 \\
\hline Haemoglobin $(\mathrm{g} / \mathrm{dL})$ & 2.8 & 4.0 & 5.3 & 5.8 & 6.4 \\
Platelet count $\left(\times 10^{9} / \mathrm{L}\right)$ & 26 & 21 & 15 & 20 & 80 \\
White cell count $\left(\times / 0^{9} / \mathrm{L}\right)$ & 2.6 & 1.62 & 1.44 & 3.09 & 2.77 \\
Neutrophils $\left(\times 10^{9} / \mathrm{L}\right)$ & 1.22 & 0.87 & 0.86 & 1.30 & 1.05 \\
Sodium $(\mathrm{mmol} / \mathrm{L})$ & 130 & 132 & 132 & 135 & 138 \\
Potassium $(\mathrm{mmol} / \mathrm{L})$ & 3.2 & 3.0 & 2.9 & 3.8 & 3.8 \\
Creatinine $(\mathrm{umol} / \mathrm{L})$ & 89 & 75 & 64 & 64 & 68 \\
C-Reactive Protein $(\mathrm{mg} / \mathrm{L})$ & 28 & 29 & 20 & - & 22 \\
\hline
\end{tabular}

2 of admission. Vital signs remained stable throughout the admission. Peripheral blood counts also improved thereafter (see table 3). Subsequent measurement of $B_{12}$ and folate levels at follow-up outpatient appointment showed normalisation.

\section{Discussion}

The case presentation and results of microbiological, immunological and radiological investigations described above support our hypothesis that the occurrence of pyrexia in this patient is attributable directly to the presence of megaloblastic anaemia secondary to folate deficiency. We extensively investigated for other possible infective and inflammatory conditions but found no other contributory cause.

Fever is a feature of megaloblastic anaemia that has been described previously in the literature $[1,2]$ and is thought to be more common in patients with moderate to severe anaemia and thrombocytopenia [3] The level of pyrexia usually correlates with degree of anaemia and resolves one to three days after adequate vitamin supplementation [4], as illustrated by the case we present (see figure 1). Failure of resolution after vitamin supplementation should, however, suggest the probability of an alternative cause for the pyrexia [1].

The exact cause of pyrexia in megaloblastic anaemia is not known and previously it has been hypothesised that it may reflect a defect in oxygenation to the temperature regulatory centres in the brain [5]. However, this theory does not explain why the fever seen in patients with megaloblastic anaemia is not a recognised feature of other forms of anaemia. Another proposed mechanism is that megaloblastic anaemia leads to hyperplasia and thus increased activity within the bone marrow leading to systemic pyrexia $[1,5]$. The mechanism of how pyrexia is induced by an over-productive marrow is, however, unclear. In previous case series, treatment with $\mathrm{B}_{12}$ and folic acid has been shown to cause rapid resolution of fever and this is felt to be due to immediate improvement in ineffective 


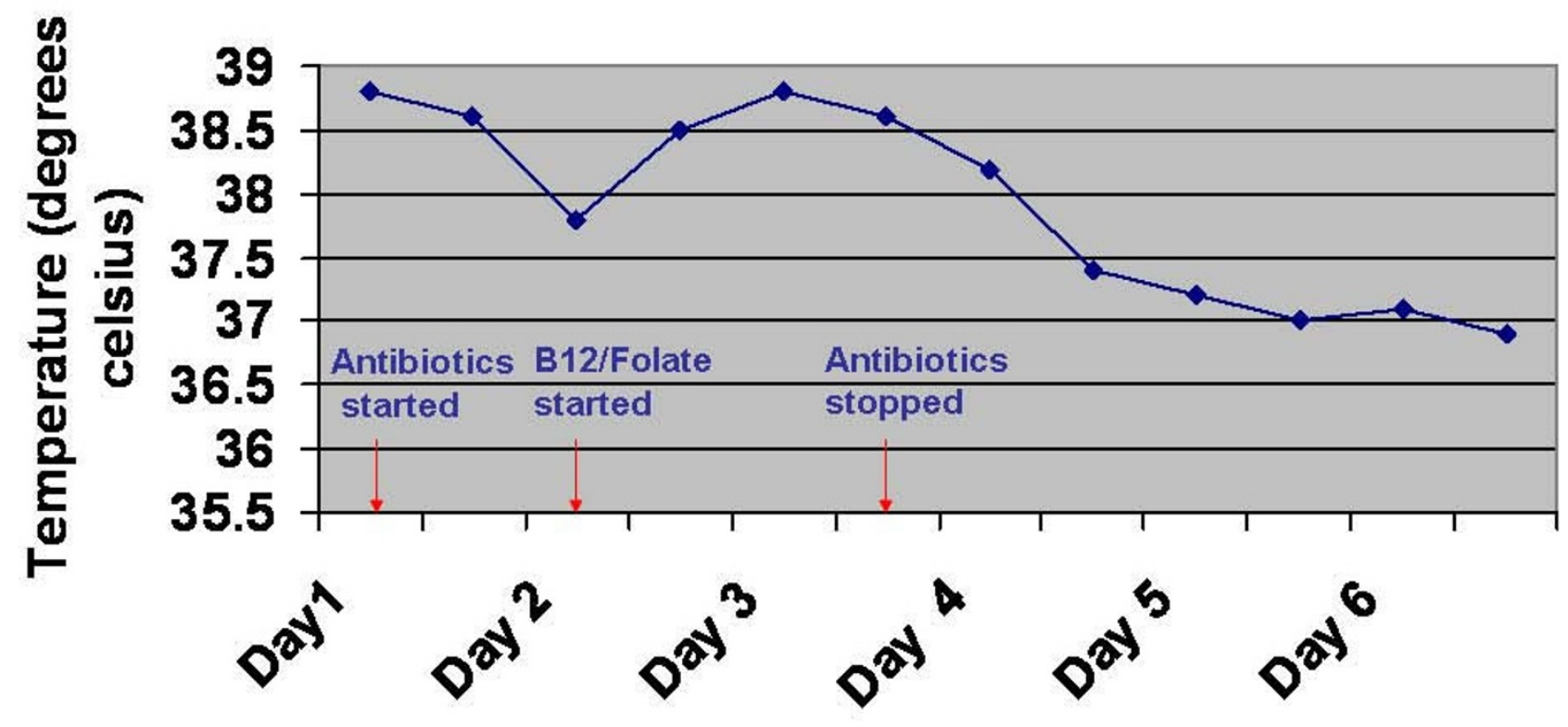

Figure I

Patient temperature chart.

erythropoiesis [1]. This rapid resolution of fever was also seen in the case we describe and further supports our hypothesis of pyrexia caused directly by folate deficiency.

\section{Conclusion}

Megaloblastic anaemia is a rare but reversible cause of pyrexia that should be considered in any patient who presents with a pyrexial illness without other infective or inflammatory source. This is a particularly important consideration as such patients with fever and a pancytopenic peripheral blood picture may initially be wrongly treated with broad spectrum antibiotics as part of a neutropenic sepsis protocol (as demonstrated by the case we describe). Measurement of $\mathrm{B}_{12}$ and folate levels should be requested as part of a screen sent for any patient who is pyrexial without an obvious cause.

\section{Consent}

Written informed consent was obtained from the patient for publication of this case report and accompanying images. A copy of the written consent is available for review by the Editor-in-Chief of this journal.

\section{Competing interests}

The authors declare that they have no competing interests.

\section{Authors' contributions}

Ar $S$ performed the literature search and wrote the initial manuscript. NG and An S were major contributors in writ- ing and editing the manuscript. HJ was the supervising consultant involved in the case, made the diagnosis and had the original idea to write up as a case report.

\section{References}

I. McKee LC: Fever in Megaloblastic anaemia. South Med J 1979, 72(II): 1423-1424.

2. Gatenby PB: Clinical analysis of $\mathbf{1 0 0}$ cases of severe Megaloblastic anaemia of pregnancy. $\mathrm{Br}$ Med J 1960, 2(5206): I I I I- I I 4 .

3. Hoffbrand HV: Megaloblastic anaemia and miscellaneous deficiency anaemias. In Oxford Textbook of Clinical Medicine Volume 3. 4th edition. Edited by: Warrell DA, Cox TM, Firth JD, Benz Jr. Oxford: Oxford University press; 2003:659-675.

4. Carpenter CL, Patalas ED: Case 40-A 38 year old woman with gastric adenocarcinoma. New Eng J Med 2000, 343: I 95 I- I 958.

5. Davidson S: Clinical picture of pernicious anaemia prior to introduction of liver therapy in 1929 and in Edinburgh subsequent to 1944. Lancet 1957, I:241-3.

Publish with Biomed Central and every scientist can read your work free of charge

"BioMed Central will be the most significant development for disseminating the results of biomedical research in our lifetime."

Sir Paul Nurse, Cancer Research UK

Your research papers will be:

- available free of charge to the entire biomedical community

- peer reviewed and published immediately upon acceptance

- cited in PubMed and archived on PubMed Central

- yours - you keep the copyright
BioMedcentral 